\title{
INNER SHELF CURRENTS OFF PONTA NEGRA BEACH, NATAL, RN, BRAZIL
}

\author{
Fernando Ribeiro ${ }^{1}$, Felipe Mendonça Pimenta ${ }^{1}$ and Helenice Vital ${ }^{2}$
}

\begin{abstract}
This work characterizes the inner shelf circulation off Ponta Negra Beach, Rio Grande do Norte state (Brazil). Near-bottom currents and sea level data are analyzed along with wind data from the ERA-Interim dataset (ECMWF) and historical sea level data from the Port of Natal, provided by the National Oceanographic Database (BNDO). Time series are analyzed in time and frequency domains. Currents are further converted into along- and cross-shelf components for their correlation with wind and sea level data. Ponta Negra near-bottom along-shelf currents are predominantly in the northward direction, with low directional variability and strong correlation ( $r \sim 0.71$ ) with the along-shelf wind component. The along-shelf flow is dominated by the subtidal frequency band, which accounts for $65 \%$ to $81 \%$ of the energy spectra. Cross-shelf currents are controlled by tides and winds. Sea level variations are dominated by tides make up $98 \%$ of the spectral energy. Subtidal sea level variability is well correlated to winds and currents, but demonstrates very low amplitude.
\end{abstract}

Keywords: Ponta Negra, winds, tides, residual currents, inner shelf circulation.

RESUMO. Este trabalho caracteriza as correntes da plataforma continental interna (PCI) da costa oriental do estado do Rio Grande do Norte, adjacente à Praia de Ponta Negra em Natal. Dados inéditos de correntes próximas ao fundo e nível do mar são analisados junto a uma série de ventos derivados da Reanálise ERA-Interim (ECMWF) e dados de nível do Porto de Natal, fornecidos pelo Banco Nacional de Dados Oceanográficos (BNDO). Séries temporais são analisadas no domínio do tempo e da frequência. Correntes são convertidas em componentes ao longo e através da costa para correlação com o vento e nível do mar. As correntes de fundo ao longo da costa são predominantemente na direção Norte, revelando baixa variabilidade direcional e forte correlação ( $r \sim 0,71)$ com a componente do vento paralela à costa. Correntes ao longo da costa são dominadas pela banda de frequência subtidal, que compõe de $65 \%$ a $81 \%$ da energia espectral. Correntes através da costa são controladas pelas marés e pelo vento. Variações de nível do mar são controladas pelas marés que perfazem $98 \%$ da energia espectral. A variação subtidal do nível do mar é bem correlacionada ao vento, mas apresenta baixa amplitude.

Palavras-chave: Ponta Negra, vento, marés, correntes residuais, plataforma continental interna.

\footnotetext{
1 Universidade Federal de Santa Catarina (UFSC), Centro de Ciências Físicas e Matemáticas (CFM), Programa de Pós-Graduação em Oceanografia, Campus Trindade, Rua Eng. Agronômico Andrey Cristian Ferreira, Blocos Modulados do Centro de Ciências Físicas e Matemáticas, CFM, Corredor B, Sala B-14, 88040-900 Florianópolis, SC, Brazil. Phone: +55(48) 3721-2701 - E-mails: fernandolageano@gmail.com; felipe.pimenta@ufsc.br

2Universidade Federal do Rio Grande do Norte (UFRN), Laboratório de Geologia e Geofísica Marinha e Monitoramento Ambiental, Departamento de Geologia, PPG Geodinâmica e Geofísica, Av. Sen. Salgado Filho, 3000, s/n, Campus Universitário, Lagoa Nova, Caixa Postal 1596, 59072-970 Natal, RN, Brazil. Phone: +55(84) 3342-3916 - E-mail: helenice@geologia.ufrn.br
} 


\section{INTRODUCTION}

Brazil's continental shelf has a wide diversity of tropical and subtropical environments. Extending over 6,400 km, its width varies from tens of kilometers in certain stretches to hundreds of kilometers in others. The shelf break starts at a depth ranging from 40 to 180 meters (Castro \& Miranda, 1998). Additionally, there is substantial geographic variability of the physical forcings that affect the circulation, such as the winds, tides, waves and river outflows.

This study analyzes near-bottom inner shelf currents off Ponta Negra Beach, city of Natal, Rio Grande do Norte state. Ponta Negra ("Black Point") is located in the eastern part of the Northeast Brazilian Tropical Shelf (NEBTS) (Fig. 1). The data analyzed here are from currents and sea level measured $3 \mathrm{~km}$ from the beach at the $10 \mathrm{~m}$ isobath, a region identified as the inner continental shelf (ICS). In general, the ICS refers to the transition region between the continental and marine domains. From a sedimentological standpoint, it is defined as the region outside the surf zone extending to a depth where the waves are still able to agitate sedimentary deposits (Wright, 1995). The definition used here, and employed by physical oceanographers, differs in the delineation of the ICS outer boundary. This limit is defined as the region where the surface and bottom Ekman layers start to interact (Lentz, 1994; Garvine, 2004). The mooring we analyze is located in relatively shallow waters compared to typical Ekman layer depths, so is most likely situated in a region governed by the inner shelf dynamics ${ }^{3}$.

These are regions where the flow adjusts to the presence of the coastline, and its dynamics play a fundamental role in the destination of contaminants and sediments. Inner shelf currents can respond to wind stress (local or remote), pressure gradients, wave incidence and tidal action (Lentz, 1994; Mellor, 1996). The outflow from rivers can also generate residual density driven currents (Garvine, 1999; Pimenta et al., 2011). The variability of these interactions occurs on time scales that range from a few minutes to several days, requiring measurement programs with high sampling frequency and preferably long duration (Miranda et al., 2002).

Few studies involving current observations have been published for the Brazilian continental shelf. Among these are Zavialov et al. (2002) and Costa \& Möller (2011) for the shelf of Rio Grande do Sul state. Pimenta et al. (2004) described the mid-shelf currents off Santa Catarina Island with drift data derived from a moored buoy. Castro et al. (2013) and Teixeira et al. (2013) described the dynamics of inner shelf currents off Caravelas, Abrolhos Banks, BA. Dias et al. (2011) analyzed ADCP data from the coast of Ceará, near the mouth of the Jaguaribe River. Geyer \& Kineke (1995), Beardsley et al. (1995) and Lentz (1995) all conducted circulation studies for the Amazon continental shelf. There is, however, a strong need for systematic studies of the NEBTS, especially the eastern part of Rio Grande do Norte (RN) state, where the capital of Natal is located (Vital et al., 2010; Vital, 2014).

Ponta Negra Beach in Natal has undergone intense urban occupation in the last decade. Erosional processes started to impact the coast, so that a breakwater was built to protect the beach (Pereira, 2013). Clandestine pipes, however, still discharge raw sewage to the storm-water drainage system, which impairs the beach water quality.

In order to fill the gap in observations for Ponta Negra, a field program was designed to measure current and sea level variability. The monitoring program was performed to allow a first description of the currents, also providing fundamental information for numerical modeling and coastal management applications. Here we analyze this dataset, providing a description of the circulation in response to wind and tidal forcing. The time series obtained sum up to 96 days of observations, which covers the spring, summer and fall seasons.

This work is organized in four remaining sections. Section 2 describes the study region, highlighting the mooring position, tide gauge and the characteristics of Ponta Negra Beach. Section 3 describes the database of currents, sea level and winds, while section 4 describes the results. Section 5 contains the summary and conclusions.

\section{STUDY AREA}

The area studied is the inner continental shelf (ICS) off the eastern coast of the state of Rio Grande do Norte, adjacent to Ponta Negra Beach in Natal ( $5^{\circ} 51^{\prime} \mathrm{S}$ and $\left.35^{\circ} 8^{\prime} \mathrm{W}\right)$. The region is located in the eastern sector of the Northeast Brazilian Tropical Shelf (NEBTS), which extends from the Parnaíba Delta at $2^{\circ} S$ to the Abrolhos Bank at $20^{\circ} \mathrm{S}$ (Vital, 2014). This portion of the shelf presents mixed sedimentation (carbonaceous-siliciclastic sediments) and is characterized by narrow width and shallow waters, when compared to other parts of the Brazilian shelf (Vital et al., 2010; Vital, 2014). The shelf width ranges from $18 \mathrm{~km}$, north of Poteng

\footnotetext{
${ }^{3}$ Surface and bottom Ekman layers are presumably too thick for the depth of our mooring. Estimating their thickness by $D=(2 K v /|f|) 1 / 2$ for $5^{\circ} \mathrm{S}$ and a turbulent viscosity range of $10^{-2}=\mathrm{Kv}=10^{-3} \mathrm{~m}^{2} \mathrm{~s}^{-1}$, we obtain $12=D=40 \mathrm{~m}$. So boundary layers are expected to interact and occupy the entire depth. In highly stratified environments, however, an inviscid interior is bound to exist (see Garvine, 2004 and Pimenta et al., 2008).
} 


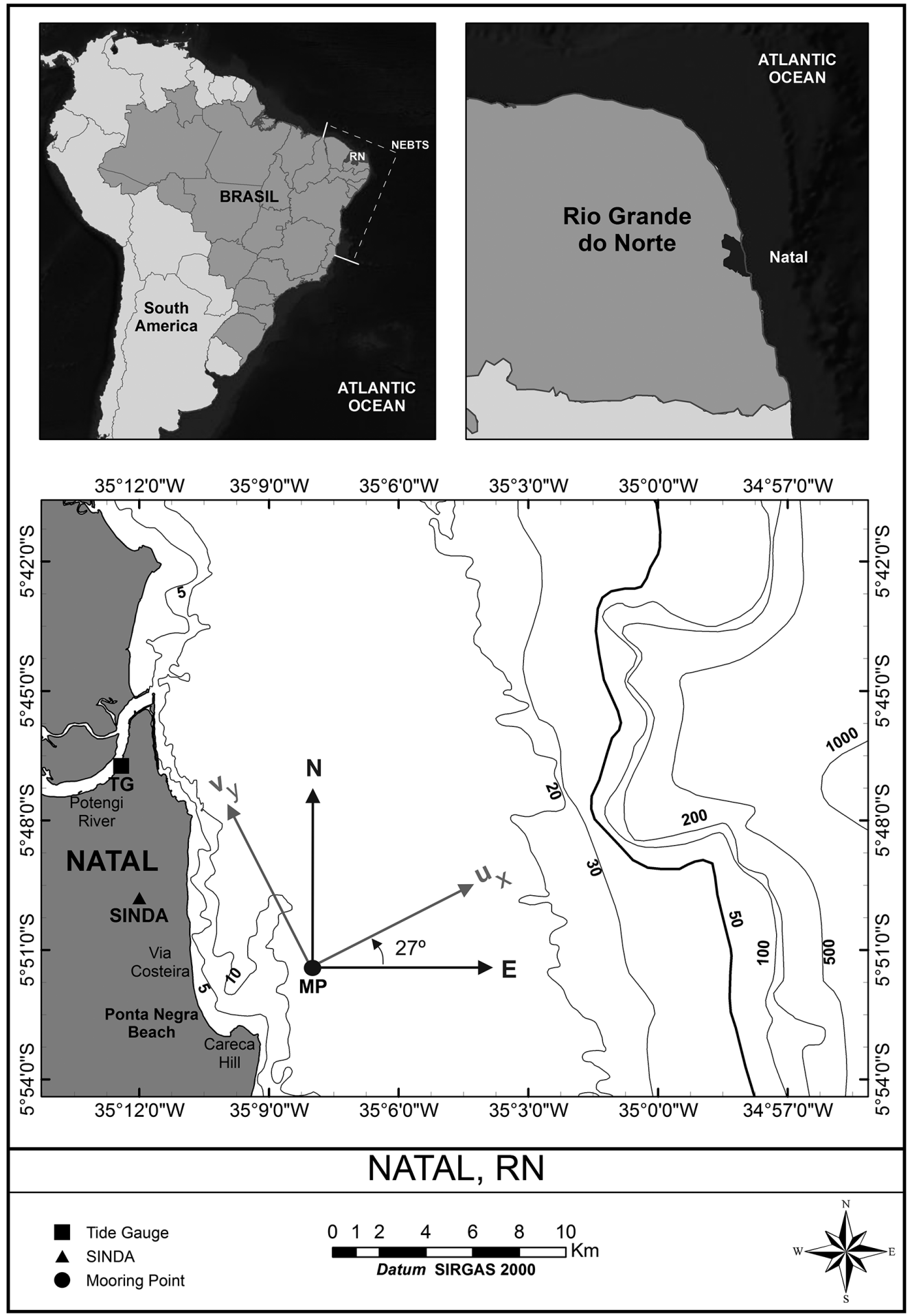

Figure 1 - Location of Ponta Negra Beach, bordered by Morro do Careca in the south and Via Costeira in the north. Isobaths indicate the depth in meters. The mooring point (MP) is indicated by a black bullet. The tide gauge of the Port of Natal is indicated by a square (TG). The indicated reference frame $U x$ and $V y$ was rotated $27^{\circ}$ counterclockwise from true north (see section 4.3 for this angle calculation). The shelf break is indicated by a thick line at the isobath of 50 meters. 
River mouth, to $30 \mathrm{~km}$ off Morro do Careca, where the break has an average depth of $60 \mathrm{~m}$ (Fig. 1). In this figure it is not possible to identify the width of the NEBTS.

The external portion of the shelf is under influence of the North Brazil Undercurrent (NBUC), with integrated transport of $26.5 \pm 3.7$ Sv between 0 and 1100 m near $5^{\circ} \mathrm{S}$ (Schott et al., $2005)^{4}$. The region is characterized by water masses of tropical origin ( $\mathrm{T}>20^{\circ} \mathrm{C}$ and $\mathrm{S}>36 \mathrm{psu}$ ) (Silveira et al., 2000) and a mesotidal regime (Pugh, 2004) with tidal range between 0.85 and $2.30 \mathrm{~m}$ (Frazão, 2003). The persistent forcing of the trade winds is another distinct feature of this region (Cavalcanti et al., 2009; Silva et al., 2016).

The region of Natal has variable annual rainfall, with a dry season ( $50 \mathrm{~mm}$ month-1) extending from August to March, mostly associated with the sea breeze circulation. The rainy season ( $500 \mathrm{~mm} \mathrm{month}^{-1}$ ) occurs from April to July and is associated with the Intertropical Convergence Zone (ITCZ) (Oliveira \& Silva, 2013). The most significant fluvial discharge is from the Potengi River, to the north of the study region, with average $5 \mathrm{~m}^{3} \mathrm{~s}^{-1}$ in the rainy period, and nearly $1 \mathrm{~m}^{3} \mathrm{~s}^{-1}$ in the dry period (Carrascoza, 2011) (Fig. 1).

The coastline is irregular and predominantly formed by a zeta $(\zeta)$ embayment form, with Via Costeira Beach to the north and Morro do Careca dune system to the south (Vital, 2006) (Fig. 1).

\section{DATABASE}

In this section we present the dataset used, described in three subsections: currents and sea level at the mooring point, tide gauge of the Port of Natal, and winds. Table 1 presents the period covered by the sea level data of the Port of Natal, measured by the tide gauge (TG), the three campaigns carried out at the mooring point (MP), as well as the coverage of the wind data obtained from the ERA-Interim Reanalysis (Dee et al., 2011).

\section{Currents and Sea Level at the Mooring Point}

During the campaigns, we used an InterOcean Systems model S4 (electronic-magnetic) current meter. The S4 measures electromagnetic field changes caused by currents, providing the flow speed and direction. The equipment also has a pressure sensor to derive sea level data. The S4 has sampling frequency of $2 \mathrm{~Hz}$ and was configured to sample 10-minute averages at intervals of 30 minutes.

The S4 was moored at a distance of about $3 \mathrm{~km}$ from the coastline at the $10 \mathrm{~m}$ isobath (551'26"S and $\left.35^{\circ} 8^{\prime} 14^{\prime \prime} \mathrm{W}\right)$. The

\footnotetext{
${ }^{4} \mathrm{~Sv}=1$ Sverdrup $=10^{6} \mathrm{~m}^{3} \mathrm{~s}^{-1}$
}

current meter was positioned 1.5 meters above the seafloor, within the bottom boundary layer (Fig. 1).

Currents and sea level data were obtained in three campaigns, conducted in the spring, summer and fall, with a total of 96 days (Table 1). The extension of each of the campaigns was enough to allow the separation of the tidal components: M2 and S2 (minimum recording of 14.7 days); and K1 and 01 (13.7 days) (Emery \& Thomson, 2001). The data from the winter campaign were lost due to technical problems with the equipment.

\section{Tide Gauge at the Port of Natal}

The sea level data of the Port of Natal was obtained from the National Oceanographic Database (BNDO). The time series was collected by a tide gauge (buoy with counterweight) installed at the end of the pier of the Mineral Resource Research Agency (CPRM), located $3.5 \mathrm{~km}$ inland from the Potengi River mouth ( $5^{\circ} 46^{\prime} 43.18^{\prime \prime} \mathrm{S}$ and $\left.35^{\circ} 12^{\prime 2} 26.87^{\prime \prime} \mathrm{W}\right)$ (Fig. 1). The dataset has hourly samples and covers the period from April 1, 2005 to May 31, 2006 (Table 1).

\section{Winds}

The wind data employed are derived from the ERA-Interim program, managed by the European Centre for Medium-Range Weather Forecasts (ECMWF) (Dee et al., 2011). ERA-Interim is a global atmospheric reanalysis that covers the period from 1979 to the present. The model has a spatial resolution of $0.75^{\circ}$ $\times 0.75^{\circ}(\sim 80 \mathrm{~km})$ and a time resolution of 6 hours. The data were extracted for a region between $32^{\circ} \mathrm{W}$ and $42^{\circ} \mathrm{W}$ and $2^{\circ} \mathrm{S}$ and $12^{\circ} \mathrm{S}$. This period overlaps all the sea level and current time series analyzed. ERA-Interim winds were well correlated ( $r \sim 0.71)$ with those measured at a local meteorological station from SINDA/INPE, but the station is located in an urban area with complex relief, and the data also do not cover the entire period of our observations (Fig. 1). Due to its good representativeness of oceanic conditions, the ERA-Interim was employed to perform all wind stress analysis.

\section{RESULTS \\ Wind Regime}

The winds in the Ponta Negra region are primarily controlled by the trade wind system and are secondarily modulated by the sea breeze (Teixeira, 2008; Barros, 2013). The trade winds are prevailing easterly low-level winds, and in the case of Brazil, they are generated dominantly by the circulation between the 
Table 1 - Periods of the data series on sea level at the Port of Natal (TG), currents and sea level at the mooring point (MP) and wind data. MP winter data were last due to technical problems with the S4 current meter.

\begin{tabular}{|c|c|c|c|}
\hline Data & Season & Period & $\begin{array}{c}\text { Number } \\
\text { of Days }\end{array}$ \\
\hline $\begin{array}{c}\text { Historical sea level } \\
\text { (TG, Port of Natal) }\end{array}$ & All & April 1, 2005 to May 31, 2006 & 420 \\
\hline $\begin{array}{c}\text { Currents and sea level } \\
\text { (MP, campaign 1) }\end{array}$ & Spring & October 9, 2013 to November 7, 2013 & 30 \\
\hline $\begin{array}{c}\text { Currents and sea level } \\
\text { (MP, campaign 2) }\end{array}$ & Summer & January 11, 2014 to February 12, 2014 & 33 \\
\hline $\begin{array}{c}\text { Currents and sea level } \\
\text { (MP, campaign 3) }\end{array}$ & Fall & March 14, 2014 to April 15, 2014 & 33 \\
\hline $\begin{array}{c}\text { Winds } \\
\text { (ERA-Interim Reanalysis) }\end{array}$ & All & November 1, 2004 to April 15, 2014 & 3453 \\
\hline
\end{tabular}

South Atlantic Subtropical High and the Intertropical Convergence Zone (ITCZ) (Cavalcanti et al., 2009). In normal years, the ITCZ migrates northward in August and September (spring), when the southeasterly trade winds blow over northeast Brazil with more intensity. The ITCZ's southernmost position is reached in March and April (fall) (Silva et al., 2016), when low winds and heavy rainfall are usually expected. Sea and land breezes are meteorological phenomena with daily frequency, present in coastal regions due to spatial differences of air pressure that arise from the different heat capacities of land and water (Teixeira, 2008). In the Natal region, the winds blow predominantly from the southeast direction $86 \%$ of time. This variability is explained by its proximity of the coast due to sea breezes (Barros, 2013).

The wind data from the ECMWF were interpolated to hourly frequency and then decomposed into along- and cross-shelf components. For this we considered an angle of $\theta=-27^{\circ}$ in relation to true north ${ }^{5}$. The wind data were then converted into along $\tau_{y}$ and cross-shelf $\tau_{x}$ wind stress components $\left(\mathrm{N} \mathrm{m}^{-2}\right)$ (Csanady, 1982):

$$
\begin{aligned}
\tau_{x} & =\rho_{a} C_{d}|\vec{W}| W_{x} \\
\tau_{y} & =\rho_{a} C_{d}|\vec{W}| W_{y}
\end{aligned}
$$

where $\rho_{a}=1.25 \mathrm{~kg} \mathrm{~m}^{-3}$ is the air density, $|\vec{W}|$ denotes the magnitude of the wind speed vector, $W_{x}$ represents the cross-shelf, and $W_{y}$ the along-shelf wind components.

$$
C_{d}=\left\{\begin{array}{ll}
1.2 & 4 \leq U 10<11 \mathrm{~m} \mathrm{~s}^{-1} \\
0.49+0.065 U 10 & 11 \leq U 10 \leq 25 \mathrm{~m} \mathrm{~s}^{-1}
\end{array} .\right.
$$

$C_{d}$ is the drag coefficient, calculated according to Large \&
Pond (1981). Here we analyze the spatial pattern of wind stress fields, as well as their directional and spectral variability.

Figure 2 presents the directions and magnitudes of the wind stress fields for the period of the three current measurement campaigns. In general, the wind stress is more intense in the oceanic region, with magnitudes greater than $0.07 \mathrm{~N} \mathrm{~m}^{-2}$. Over the northern coast of RN, the stress values reach $0.1 \mathrm{~N} \mathrm{~m}^{-2}$, with winds blowing parallel to the shore (Fig. 2). Over the continental region, the stresses were lower than $0.06 \mathrm{~N} \mathrm{~m}^{-2}$. The dominance of the southeasterly trade winds was clear during all campaigns.

The directional histograms of Figure 3 depict the dominant direction of winds just offshore of Natal (see Fig. 2 for the location). Winds usually blow from the SE quadrant, with directional variability of approximately $45^{\circ}$. The magnitude of the wind stress for Natal was largest during the spring campaign, followed by the summer and fall (Fig. 3). This agrees with the climatology reported by Silva et al. (2016), which shows the winter and spring as the windiest seasons for RN state. The average stress considering all campaigns was near $0.05 \mathrm{~N} \mathrm{~m}^{-2}$, although stress as high as $0.09 \mathrm{~N} \mathrm{~m}^{-2}$ was observed for Natal. During the spring, the directional variability was also lower than for the other seasons (Fig. 3).

The spectral analysis followed the method described by Welch (1967), using a Hanning window, with $1 / 3$ of the total length of the series and a $50 \%$ overlap. This procedure results in an estimate of the average spectral density calculated from five segments. The application of this "windowing" procedure causes loss of spectral resolution, but increases the statistical reliability of energy density per frequency band (Costa \& Möller, 2011).

\footnotetext{
${ }^{5}$ This angle refers to the principal axes found for inner shelf currents, see section 4.3.
} 

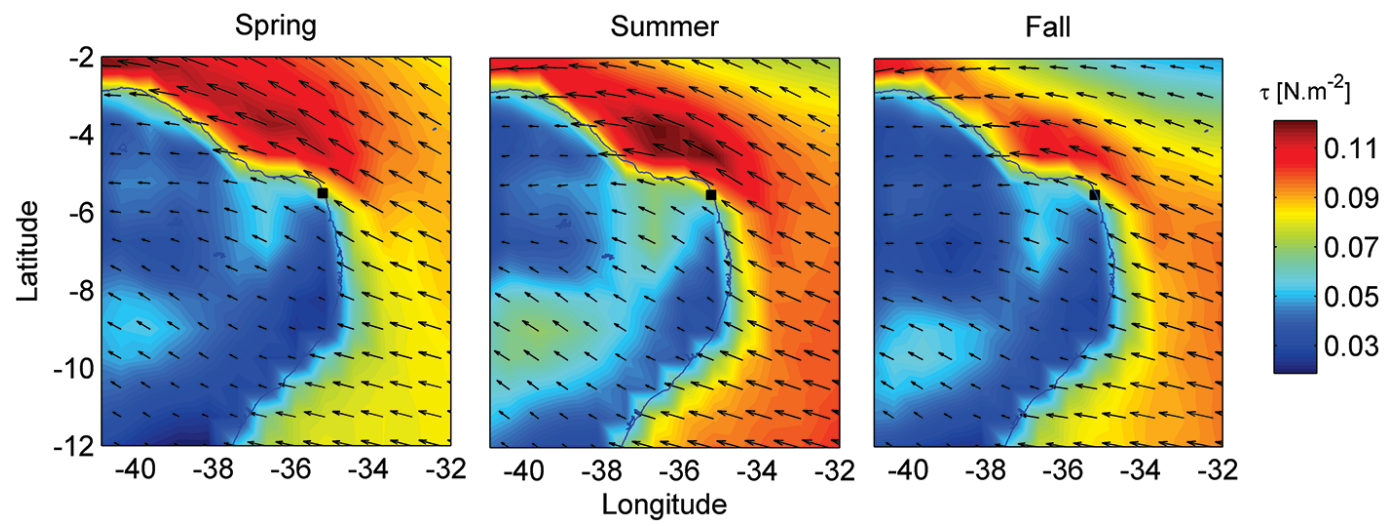

Figure 2 - Average wind stress fields derived from the ERA-Interim Reanalysis from the ECMWF. The color scale represents the magnitude of the wind stress $\left(\mathrm{N} \mathrm{m}^{-2}\right)$ and the vector field indicates the wind direction. Each season corresponds to the time period of the current meter campaign (Table 1). The black square indicates the position of the grid point used for extraction of the wind time series used in all correlation and spectral analyses (see Figs. 3, 4, 7, 8 and 9).
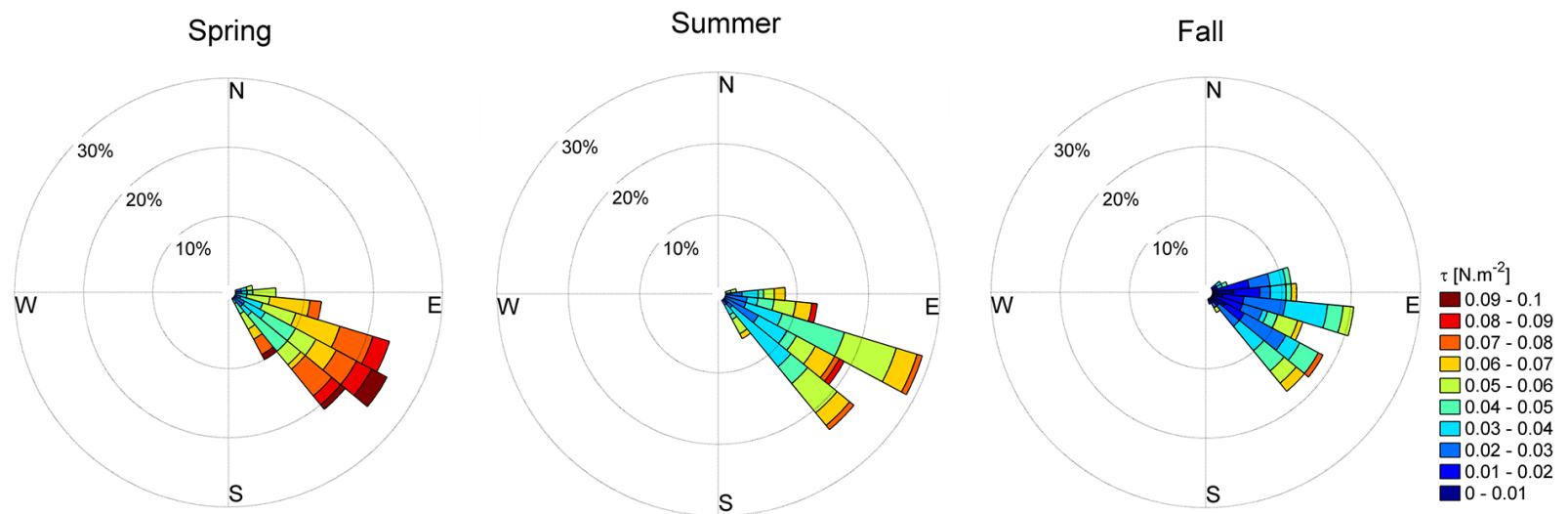

Figure 3 - Directional histogram of wind stress direction and intensity $\left(\mathrm{N} \mathrm{m}^{-2}\right)$. The panels correspond to the average winds for a grid point offshore from Natal (Fig. 1). Each bar follows the meteorological convention, indicating the direction from which the wind is blowing. The sampled time corresponds to the current measurement periods, as reported in Table 1.

The spectral density of the winds showed a similar pattern in the three seasonal campaigns (Fig. 4). The analysis revealed three dominant bands with periods of: 1 day (diurnal), 3 to 5 days, and more than 6 days. The diurnal signal of the sea breeze was apparent in the three campaigns, with the greatest relative contribution occurring in the fall. The largest energy contribution was concentrated in the low frequency band with periods longer than 10 days. A secondary peak was found with variability near 5 days, which can be associated with atmospheric wave disturbances and inertial oscillations (Neiva, 1975; Cavalcanti et al., 2009).

\section{Sea Level}

We analyzed a historical sea level time series of the Port of $\mathrm{Na}$ tal along with the sea level data from the mooring point (Table 1).
The spectral analysis of the sea level time series from the Port of Natal is presented in Figure 5a, with specific frequency bands indicated by horizontal lines. Following Zavialov et al. (2002), we integrated the fractions of energy spectra that reside within these bands: the shallow water band (SW, periods from 2 to $11 \mathrm{~h}$ ), the semi-diurnal band (SD, periods from 11 to $18 \mathrm{~h}$ ); the diurnal band (D, 18 to $30 \mathrm{~h}$ ); the meteorological forcing band (M, 30 to $240 \mathrm{~h}$ ); and the low frequency band (LF, periods over $240 \mathrm{~h}$ ).

The results of this integration, expressed as percent relative to the total energy, are given in Table 2. The semidiurnal tidal band's dominance is quite evident from the graph of Figure $5 \mathrm{a}$, covering $97.54 \%$ of the spectral energy, followed by the diurnal band $(1.02 \%)$, low frequency band $(0.48 \%)$, shallow water $(0.40 \%)$ and meteorological band $(0.28 \%)$ (Table 2). The spectral analysis of sea level from the mooring point (MP) revealed 

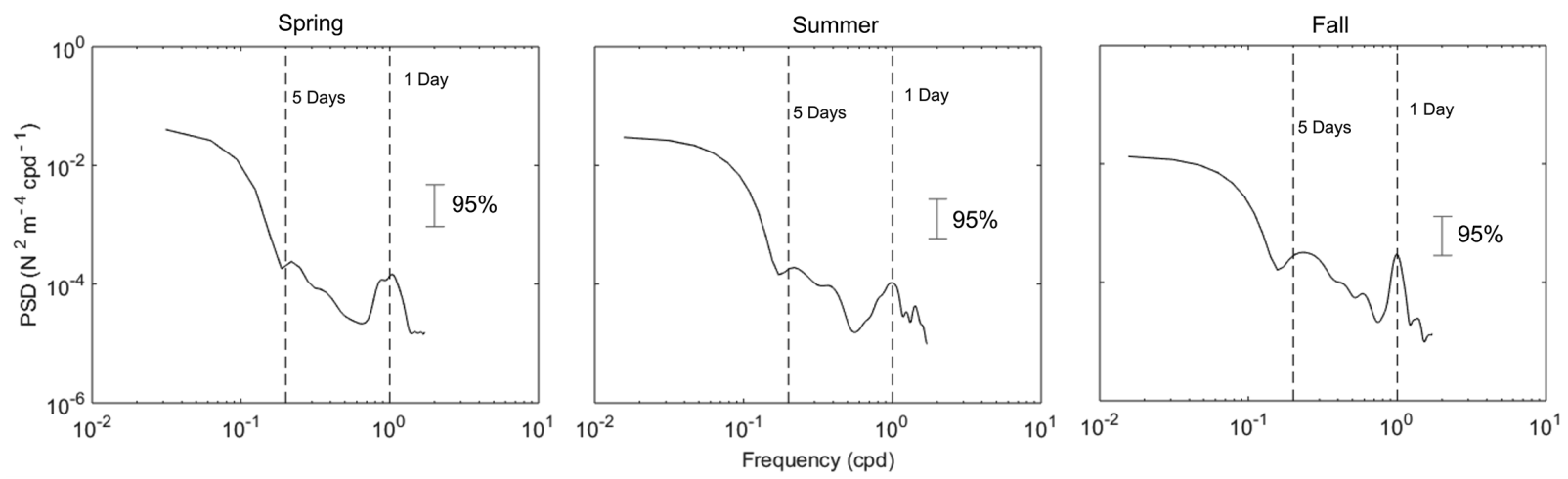

Figure 4 - Spectral density of wind stress for the spring, summer and fall seasons (Table 1). The dashed lines indicate the periods of diurnal and 5 day variability. The wind series data used here covered the same period of current measurements, as reported in Table 1.
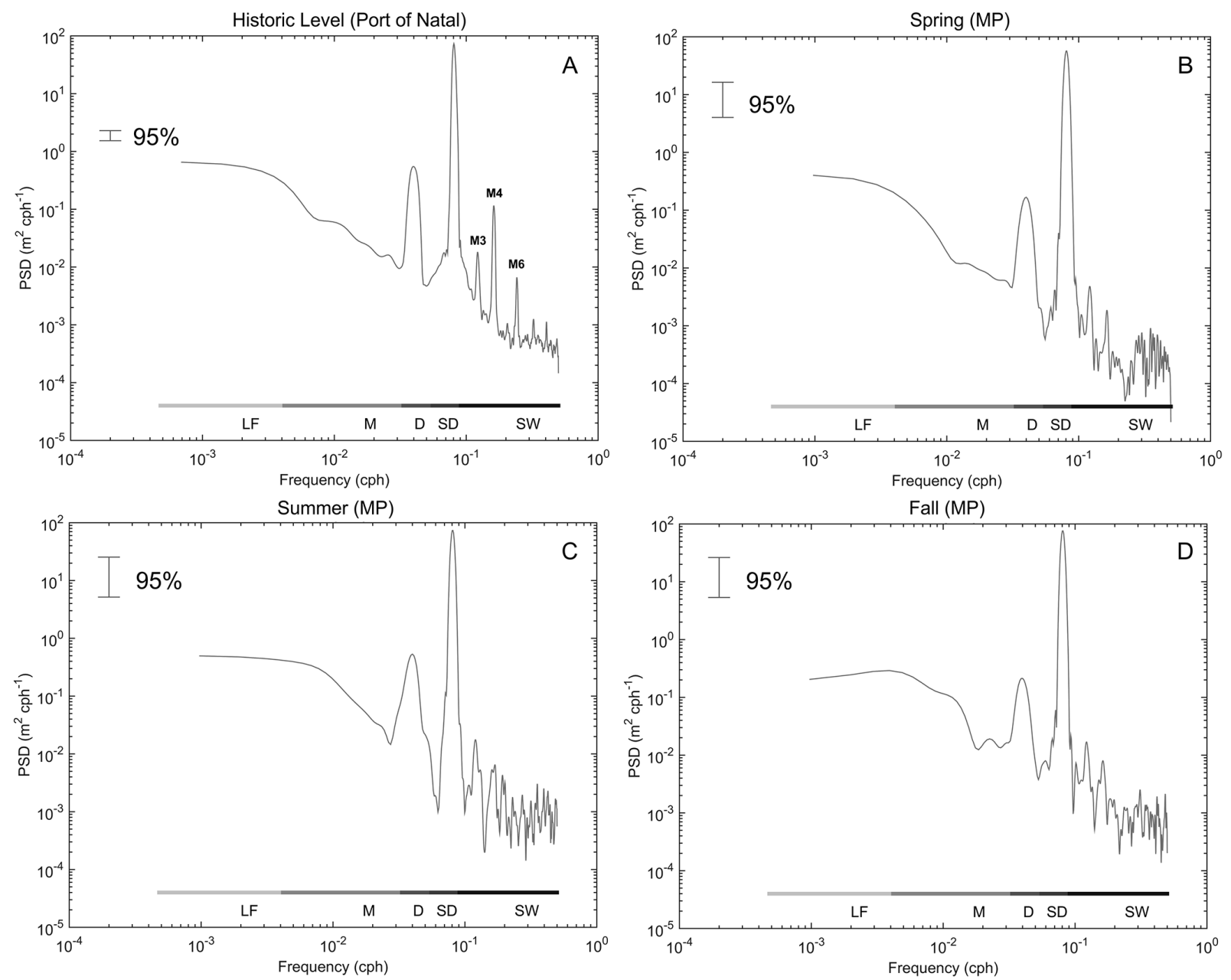

Figure 5 - Spectral analysis of the sea level for the Port of Natal (panel A) and the mooring point (MP, panels B to D) for the spring (panel B), summer (panel C) and fall (panel D). The letters LF, M, D, SD and SW refer, respectively, to the low frequency, meteorological, diurnal, semidiurnal and shallow water bands (see Table 2 for definitions). The shallow water components M3, M4 and M6 are indicated by labels. PSD refers to power spectral density $\left(\mathrm{m}^{2} \mathrm{cph}^{-1}\right)$. 
Table 2 - Energy partition derived from spectral analysis of the sea level from the Port of Natal (TG) and at the mooring point (MP). Distribution is performed according to five main frequency bands, computed for the TG and the spring, summer and fall campaigns of the MP. The locations of the TG and MP observation points are depicted in Figure 1.

\begin{tabular}{|c|c|c|c|c|c|c|}
\hline & \multirow{2}{*}{ Frequency bands (cph) } & \multirow{2}{*}{ Periods $(\mathrm{h})$} & $\begin{array}{c}\text { Port of Natal } \\
\text { (\% Energy) }\end{array}$ & \multicolumn{3}{|c|}{ Mooring Point (\% Energy) } \\
\cline { 4 - 7 } & & & All & Spring & Summer & Fall \\
\hline Low frequency & $0.00048<f \leq 0.00417$ & $240<T$ & 0.48 & 0.23 & 0.28 & 0.15 \\
\hline Meteorological & $0.00417<f \leq 0.03333$ & $30<T \leq 240$ & 0.28 & 0.13 & 0.61 & 0.33 \\
\hline Diurnal & $0.03333<f \leq 0.05555$ & $18<T \leq 30$ & 1.02 & 0.32 & 0.88 & 0.36 \\
\hline Semidiurnal & $0.05555<f \leq 0.09090$ & $11<T \leq 18$ & 97.54 & 99.26 & 98.07 & 99.02 \\
\hline Shallow water & $0.09090<f \leq 0.50000$ & $2<T \leq 11$ & 0.40 & 0.05 & 0.16 & 0.15 \\
\hline
\end{tabular}

the semidiurnal frequency as the dominant band, with more than $98 \%$ of the spectral energy (Table 2). Its spectral amplitude is also two orders of magnitude larger than the other bands (Figs. $5 b$ to $5 d$ ). The diurnal band represents less than $1 \%$ of the spectral energy. The relative importance of shallow water components was higher for the Port of Natal (Table 2).

The harmonic analysis of the sea level data was performed with the T_TIDE package developed by Palowicz et al. (2002), revealing 29 statistically significant components at $95 \%$ confidence level for the three campaigns performed at the mooring point (MP) (Table 3). This analysis showed that the semidiurnal components have the largest amplitudes, corroborating the spec- tral analysis. The components M2, S2 and N2 presented respectively amplitudes of $0.818 \mathrm{~m}, 0.272 \mathrm{~m}$ and $0.159 \mathrm{~m}$ for the MP. In turn, the diurnal components were $0.050 \mathrm{~m}$ for 01 and $0.045 \mathrm{~m}$ for $\mathrm{K} 1$, characterizing the region by a form number of 0.087 , denoting a mesotidal regime of semidiurnal characteristics

$$
N f=\frac{A K_{1}+A O_{1}}{A M_{2}+A S_{2}}=\frac{0.045+0.050}{0.818+0.272}=\frac{0.095}{1.090}=0.087 .
$$

The harmonic analysis of the sea level measured at the Port of Natal revealed 35 statistically significant constants at $95 \%$ confidence level. For compactness, only the 14 principal components are presented due to their greater importance in terms of amplitude (Table 3). The strongest components were the semidi-

Table 3 - Harmonic components in decreasing order of amplitude. Analysis conducted with data from the Port of Natal from April 1, 2005 to May 31, 2006. The data series used in the analysis for the mooring point refer to the spring (Oct. 9, 2013 to Nov. 7, 2013), summer (Jan. 11, 2014 to Feb. 12, 2014) and fall (March 14, 2014 to April 15, 2014). Data collected in UTC. The harmonic analysis was performed with the T_TIDE package developed by Palowicz at al. (2002).

\begin{tabular}{|c|c|c|c|c|c|c|}
\hline \multirow{2}{*}{ Constant } & \multirow{2}{*}{$\begin{array}{c}\text { Frequency } \\
\text { (cph) }\end{array}$} & \multirow{2}{*}{$\begin{array}{c}\text { Period } \\
(\mathrm{h})\end{array}$} & $\begin{array}{c}\text { Amplitude } \\
(\mathrm{m})\end{array}$ & $\begin{array}{c}\text { Phase } \\
\left({ }^{\circ}\right)\end{array}$ & $\begin{array}{c}\text { Amplitude } \\
(\mathrm{m})\end{array}$ & $\begin{array}{c}\text { Phase } \\
\left({ }^{\circ}\right)\end{array}$ \\
\hline M2 & 0.0805 & 12.42 & 0.818 & 202.73 & 0.784 & 211.67 \\
S2 & 0.0833 & 12.00 & 0.272 & 227.36 & 0.266 & 232.42 \\
N2 & 0.0789 & 12.65 & 0.159 & 186.75 & 0.159 & 199.79 \\
K2 & 0.0835 & 11.96 & 0.091 & 220.16 & 0.074 & 229.27 \\
01 & 0.0387 & 25.81 & 0.050 & 170.95 & 0.049 & 202.60 \\
K1 & 0.0417 & 23.93 & 0.045 & 293.91 & 0.048 & 279.13 \\
MU2 & 0.077 & 12.87 & 0.026 & 177.16 & 0.020 & 204.05 \\
Q1 & 0.0372 & 26.86 & 0.015 & 111.00 & 0.013 & 163.42 \\
L2 & 0.0820 & 12.19 & 0.012 & 223.51 & 0.028 & 213.27 \\
M3 & 0.1207 & 08.28 & 0.007 & 244.64 & 0.006 & 280.05 \\
M4 & 0.1610 & 06.21 & 0.003 & 282.31 & 0.026 & 163.78 \\
MS4 & 0.1638 & 06.10 & 0.003 & 205.44 & 0.020 & 194.50 \\
M6 & 0.2415 & 04.14 & 0.001 & 090.42 & 0.005 & 059.00 \\
2MN6 & 0.2400 & 04.16 & 0.001 & 080.75 & 0.003 & 050.74 \\
\hline
\end{tabular}


urnal M2, followed by S2 and N2, with respective values of 0.784 , 0.266 and $0.159 \mathrm{~m}$. The values of the diurnal components were 0.049 for 01 and 0.048 for $\mathrm{K} 1$. The form number was 0.092

$$
N f=\frac{A K_{1}+A O_{1}}{A M_{2}+A S_{2}}=\frac{0.048+0.049}{0.784+0.266}=\frac{0.097}{1.050}=0.092,
$$

also classifying the tidal regime as pure semidiurnal.

Although the course of the tide in the estuary is short, about 2 kilometers, there is a slight reduction of M2 amplitude and an amplification of the shallow water components M4, MS4 and M6. Their amplitude is at least five times larger for the Port of Natal than for the mooring point (Table 3). The value of the M4/M2 ratio of the Port of Natal was 0.03. The M4/M2 ratio is a measure of the distortion of the principal semidiurnal component and reflects the dissipative effects of the system as well as the transfer of spectral energy from the M2 to M4 component (Pingree \& Griffths, 1979; Miyao \& Harari, 1989).

\section{Currents}

Current data from all campaigns were recorded in the form of $U_{m}$ and $V_{m}$ components, referenced to magnetic north $\left(N_{m}\right)$. Since the mean declination of the magnetic north $N_{m}$ to the true north $N$ was $\theta=21.6^{\circ} \mathrm{W}$, the reference axis was rotated $21.6^{\circ}$ clockwise $(U$ and $V$ ). Later the hourly dataset was decomposed into along-shelf $\left(V_{y}\right)$ and cross-shelf $\left(U_{x}\right)$ components, with the along-shelf axis oriented $\theta=-27^{\circ}$ from true north (Fig. 1). This angle was found by computing the principal axis of variance of currents from analysis of empirical orthogonal functions (EOF) (Emery \& Thomson, 2001). The $U_{x}$ cross- and $V_{y}$ along-shelf components were used for the time series, correlations and spectral analysis. All current data refer to near-bottom currents, observed at $1.5 \mathrm{~m}$ above the sea floor.

\section{Directional Analysis}

The directional histograms of the current data are shown in Figure 6. The predominant direction of the currents was to the northern quadrant, with a maximum directional spread of approximately $90^{\circ}$. Spring data presented the highest directional variability. The currents were the strongest in the summer, while the weakest directional variability was observed during the fall. Regarding the seasonal distribution, the summer presented currents with median of $12.86 \mathrm{~cm} \mathrm{~s}^{-1}$, followed by fall with $8.02 \mathrm{~cm} \mathrm{~s}^{-1}$ and spring with $9.31 \mathrm{~cm} \mathrm{~s}^{-1}$. The strongest observed near-bottom currents were around $30 \mathrm{~cm} \mathrm{~s}^{-1}$.

\section{Time Series Analysis}

The time series of wind, near-bottom currents and sea level for the spring, summer and fall campaigns are illustrated in Figures 7, 8 and 9 respectively. Both the wind and current data are decomposed into their along-shelf and cross-shelf components. The filtered dataset, computed with a Lanczos low-pass filter with cutoff frequency of $43 \mathrm{~h}$, are superposed over each original series by a red line.

The results show that in general the winds blow against the coast $\left(\tau_{x}<0\right)$ and towards the north $\left(\tau_{y}>0\right)$. We never observed reversal of the cross-shelf wind component in the period of measurements, i.e., winds were predominantly onshore. The mean intensity of the cross-shelf component was on the order of $\tau_{x}=-0.05 \mathrm{~N} \mathrm{~m}^{-2}$. On rare occasions, the along-shelf winds $\tau_{y}$ reversed direction or waned in magnitude. Two examples are the eleventh day of the spring campaign (Fig. 7) and the twelfth day of the fall campaign (Fig. 9). We observed a marked diurnal periodicity, associated with the sea breeze, and a longer period of 4 to 10 days, presumably associated with atmospheric easterly wave disturbances or inertial oscillations (Cavalcanti et al., 2009).
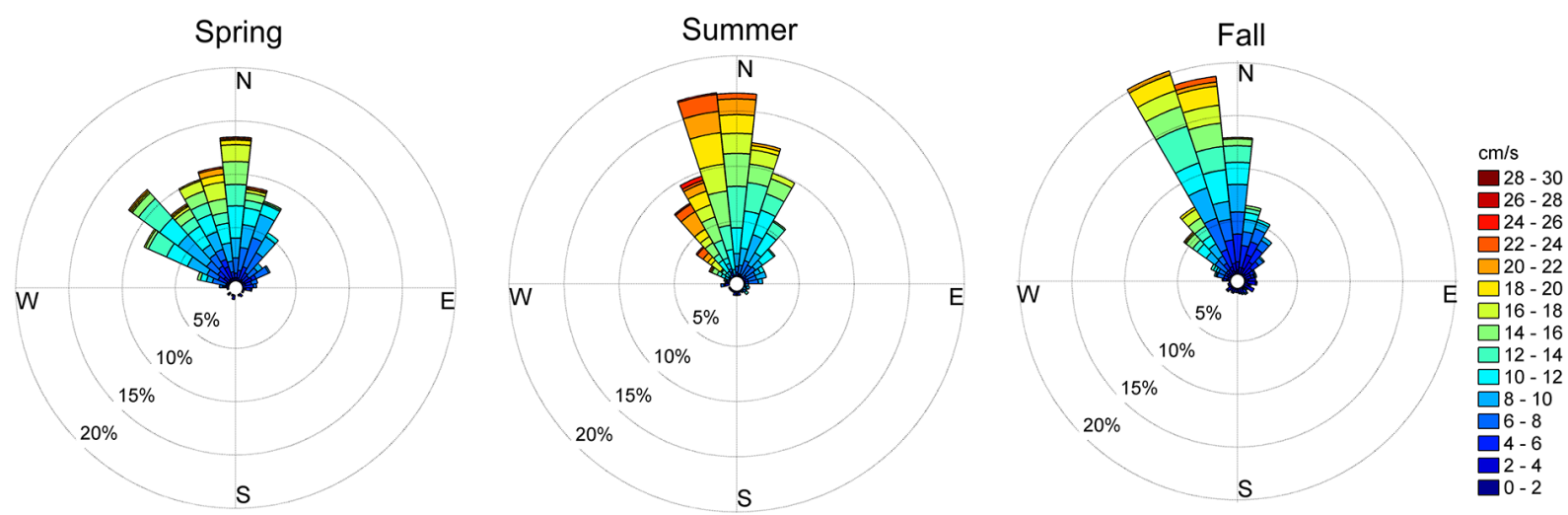

Figure 6 - Directional histograms of near-bottom currents $\left(\mathrm{cm} \mathrm{s}^{-1}\right)$ at the mooring point (MP) for the spring, summer and fall. The direction of the bars follows the oceanographic convention and points to the direction that the current flows. 
The sea level series indicate the semidiurnal predominance as well as the spring to neap tidal variability. The maximum heights during spring tides (M2+S2) were on the order of $2.2 \mathrm{~m}$, declining to $1.1 \mathrm{~m}$ during neap tides (M2-S2). The currents demonstrated a clear tidal signal, both in the along- and crossshelf components (Figs. 7 to 9). Cross-shelf currents changed in magnitude with clear semidiurnal periodicity, sometimes indicating onshore $\left(U_{x}<0\right)$ and offshore $\left(U_{x}>0\right)$ flow, and intensities on the order of $5 \mathrm{~cm} \mathrm{~s}^{-1}$. The cross-shelf component was particularly large during the summer campaign. Along-shelf currents also showed semidiurnal variability with amplitudes on the order of 5 to $10 \mathrm{~cm} \mathrm{~s}^{-1}$. Residual currents, however, were predominantly to the north $\left(V_{y}>0\right)$. The low-pass filtered component $V_{y f}$ illustrates this response by the red line in Figures 7 , 8 and 9. There is also a direct relation among the filtered series of winds $\left(\tau_{y f}\right)$, sea levels $\left(\eta_{f}\right)$ and along-shelf currents $\left(V_{y f}\right)$. In general, periods of strong along-shelf winds $\left(\tau_{y f}>0\right)$ were followed by intense currents toward the north $\left(V_{y f}>0\right)$ and higher sea level. An example of this happened on the twelfth day of spring, when the winds intensified and a relatively quick response of the currents occurred. Another example happened on the tenth day of the summer campaign.

\section{Correlation Analysis}

We calculated pairwise Pearson correlation coefficients between the filtered series of the sea level $\left(\eta_{f}\right)$, winds $\left(\tau_{x f}, \tau_{y f}\right)$ and currents $\left(U_{x f}, V_{y f}\right)$ to investigate the linear relation of the response of the ocean to wind forcing ${ }^{6}$. Table 4 lists the correlation coefficients with more that $95 \%$ confidence for the three campaigns. As can be seen, there was a strong correlation between the along-shelf winds and currents $\left(\tau_{y f}\right.$ and $V_{y f}$ ), with $r=0.77$ for spring, $r=0.70$ for summer and $r=0.66$ for fall, suggesting that winds parallel to the shore drive the inner shelf currents of Ponta Negra.

A positive correlation ( $r=0.72)$ was observed between $\tau_{y f}$ and $U_{x f}$ at the mooring point, suggesting that positive $\tau_{y f}$ are associated with positive $U_{x f}$ offshore flow near the bottom.

More generally, positive winds parallel to the shore $\left(\tau_{y f}\right)$ caused a slight sea level rise $\left(\eta_{f}\right)$ and currents toward the north $\left(V_{y f}\right)$, as illustrated by the positive correlation values $r=0.48$ (spring); 0.70 (summer) and 0.72 (fall) (Table 4). Cross-shelf winds $\left(\tau_{x f}\right)$ also promoted sea level set-up $\left(\eta_{f}\right)$, as illustrated by the negative correlation between $\tau_{x f}$ and $\eta_{f}$.
Table 4 - Pairwise correlations with more that $95 \%$ confidence between the along-shelf $\left(\tau_{y f}\right.$ and $\left.V_{y f}\right)$, cross-shelf $\left(\tau_{x f}\right.$ and $\left.U_{x f}\right)$ winds and currents and sea level $\left(\eta_{f}\right)$. The values in each cell refer to the spring (top), summer (middle) and fall (bottom)

\begin{tabular}{|c|c|c|c|c|c|}
\hline & $\eta_{f}$ & $\overline{\tau_{x f}}$ & $\overline{\tau_{y f}}$ & $\overline{U_{x f}}$ & $\overline{V_{y f}}$ \\
\hline$\eta_{f}$ & 1 & - & - & - & - \\
\hline$\tau_{x f}$ & $\begin{array}{l}-0.37 \\
-0.26 \\
-0.57\end{array}$ & 1 & - & - & - \\
\hline$\tau_{y f}$ & $\begin{array}{l}0.48 \\
0.70 \\
0.72\end{array}$ & $\begin{array}{l}-0.35 \\
-0.37 \\
-0.79\end{array}$ & 1 & - & - \\
\hline$U_{x f}$ & $\begin{array}{c}- \\
0.20 \\
0.71\end{array}$ & $\begin{array}{c}- \\
- \\
-0.62\end{array}$ & $\begin{array}{c}- \\
- \\
0.72\end{array}$ & 1 & \\
\hline$V_{y f}$ & $\begin{array}{l}0.69 \\
0.66 \\
0.49\end{array}$ & $\begin{array}{c}- \\
-0.34 \\
-0.38\end{array}$ & $\begin{array}{l}0.77 \\
0.70 \\
0.66\end{array}$ & $\begin{array}{c}- \\
- \\
0.47\end{array}$ & 1 \\
\hline
\end{tabular}

\section{Spectral Analysis of the Currents}

The spectral analysis of the components $U_{x}$ and $V_{y}$ identified a significant portion of the energy concentrated in the subtidal band. The spectrum of the components $V_{y}$ and $U_{x}$ revealed an energetic low frequency band, thus suggesting that the trade winds are an important forcing of the circulation (Figs. 10b, d, f). Table 5 presents the energy partition of the $U_{x}$ and $V_{y}$ components derived from the spectral analysis. Currents are dominated by the low frequency and meteorological bands that together account for 65 to $81 \%$ of the along-shelf component and 47 to $53 \%$ of cross-shelf component spectral energy (Table 5). During the fall campaign, wind driven along-shelf currents had relatively low magnitudes for approximately 12 days, raising the energy contribution of the tidal band (Table 5 and Fig. 9).

\section{Progressive Vector Diagram}

A progressive vector diagram (PVD) of currents represents the calculation of the theoretical displacement of a neutral particle transported by currents referenced to the North $(U$ and $V)$. The path is estimated from the following equations:

$$
\begin{aligned}
& x=x_{0}+\int_{t i}^{t f} U d t \\
& y=y_{0}+\int_{t i}^{t f} V d t
\end{aligned}
$$

where $x$ and $y$ denote the distances traveled $(m), x_{0}$ and $y_{0}$ are the points of origin, and $t i$ and $t f$ are the initial and final times,

\footnotetext{
${ }^{6}$ Here the sea level and current dataset was reduced to a $6 \mathrm{~h}$ time series for direct comparison with the wind data, which has four observations per day.
} 

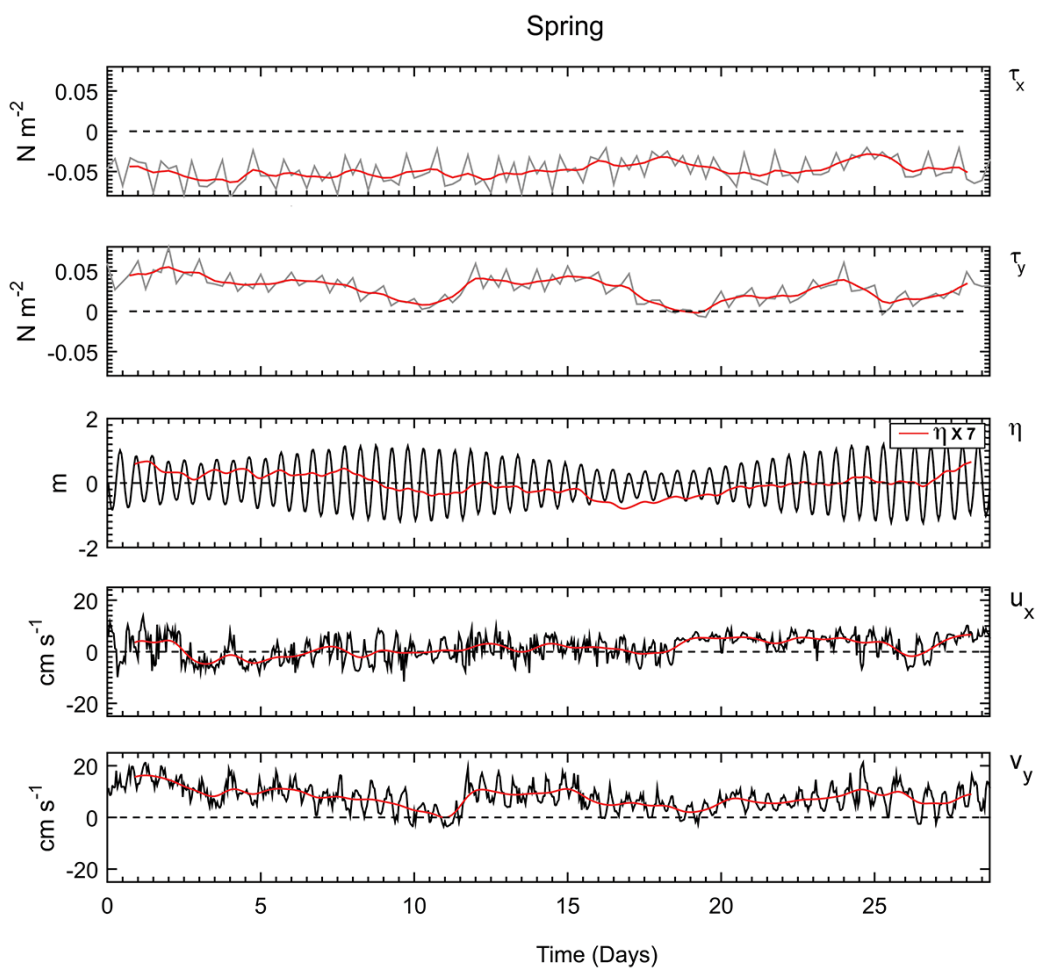

Figure 7 - Time series for the sea level $(\eta)$, wind stress cross-shelf $\left(\tau_{x}\right)$ and along-shelf $\left(\tau_{y}\right)$ components, as well as current cross-shelf $\left(U_{x}\right)$ and along-shelf $\left(V_{y}\right)$ components. Series shown here are relative to the spring campaign (Oct. 9 to Nov. 7, 2013). Low-pass filtered time series (red lines) are superposed in all panels.
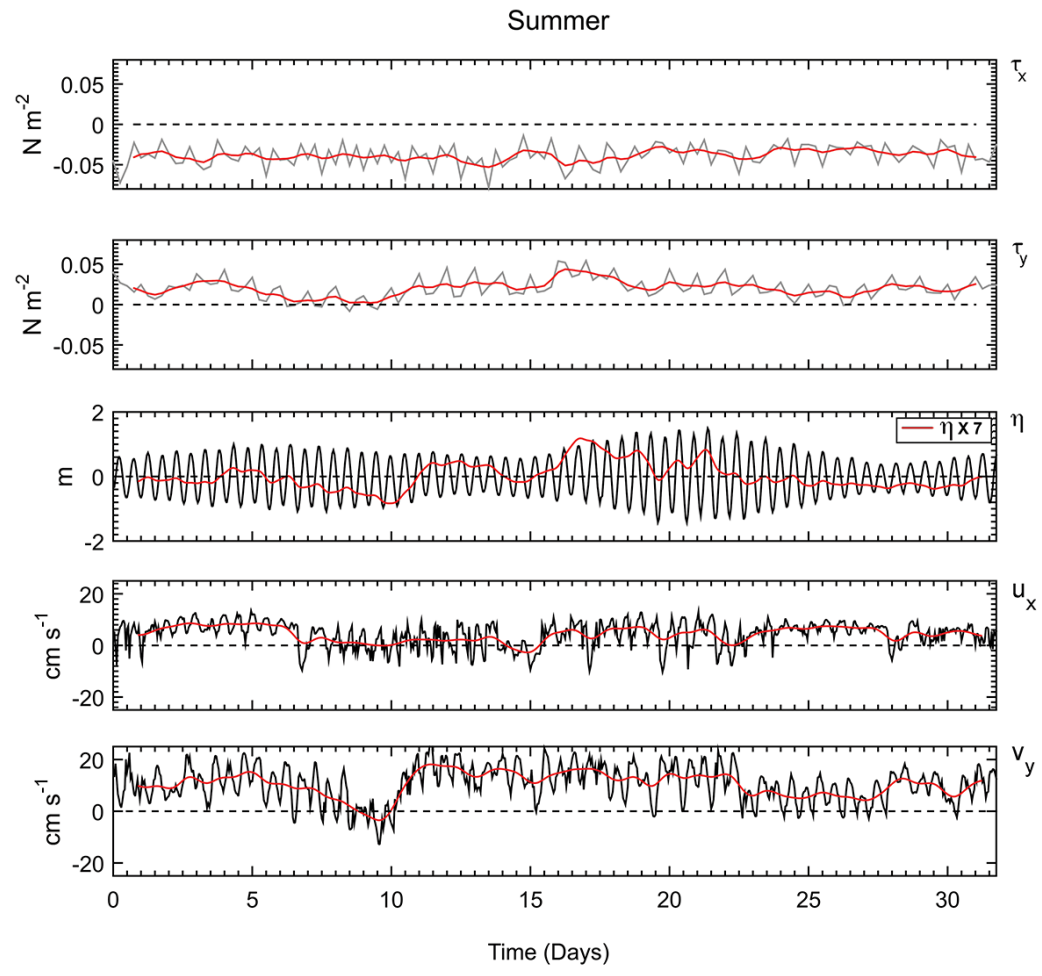

Figure 8 - Same as Figure 7, but for the summer campaign (Jan. 11 to Feb. 12, 2014). 
Fall
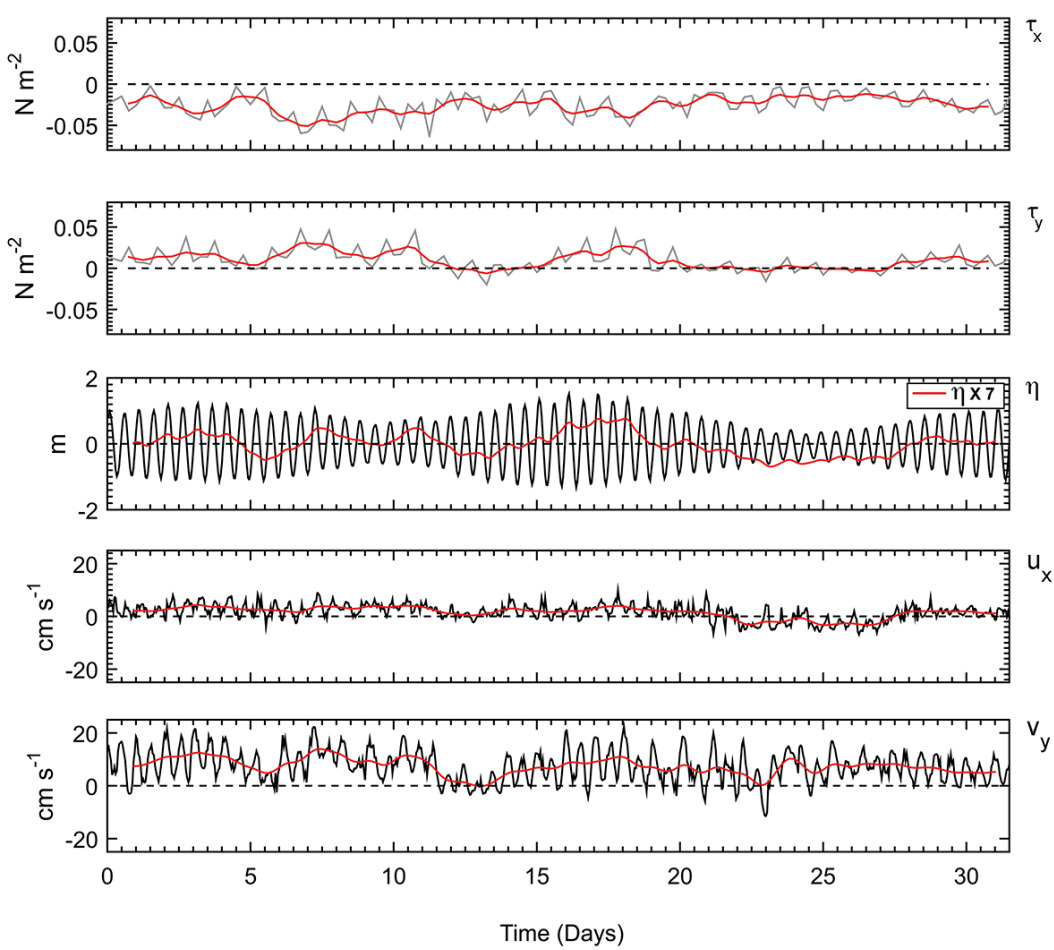

Figure 9 - Same as Figure 7, but for the fall campaign (March 14 to April 15, 2014).

Table 5 - Energy partition derived from the spectral analysis of cross- $\left(U_{x}\right)$ and along-shelf current components $\left(V_{y}\right)$. Distribution is performed according to five main frequency bands. Each partition is calculated for the spring, summer and fall campaigns.

\begin{tabular}{|c|c|c|c|c|c|c|c|}
\hline & \multirow{2}{*}{ Frequency bands (cph) } & \multicolumn{5}{|c|}{ Energy (\%) } \\
\cline { 3 - 8 } & & \multicolumn{2}{|c|}{ Spring } & \multicolumn{2}{|c|}{ Summer } & \multicolumn{3}{|c|}{ Fall } \\
\cline { 3 - 7 } & & $U_{x}$ & $V_{y}$ & $U_{x}$ & $V_{y}$ & $U_{x}$ & $V_{y}$ \\
\hline Low frequency & $0.00048<f \leq 0.00417$ & 19.99 & 57.95 & 30.30 & 56.87 & 34.36 & 46.55 \\
Meteorological & $0.00417<f \leq 0.03333$ & 27.14 & 21.57 & 22.55 & 23.96 & 18.98 & 17.96 \\
Diurnal & $0.03333<f \leq 0.05555$ & 5.20 & 2.70 & 10.09 & 3.69 & 6.88 & 7.13 \\
Semidiurnal & $0.05555<f \leq 0.09090$ & 19.88 & 12.69 & 20.57 & 12.81 & 22.53 & 24.69 \\
Shallow water & $0.09090<f \leq 0.50000$ & 27.79 & 5.09 & 16.49 & 2.68 & 17.25 & 3.67 \\
\hline
\end{tabular}

respectively. The analysis indicates the path of a floating particle in a spatially uniform and non-stationary current field. Figure 11 presents the PVD of the three campaigns. The origin represents the mooring location, to facilitate visualization and comparison of the results. The diagrams confirm that the predominant displacement caused by currents is to the north, or more specifically, along the shelf. Labels on each trajectory indicate the time elapsed in days. The residual displacements for the spring and fall were around $50 \mathrm{~km}$ to the west and $200 \mathrm{~km}$ to the north. Longer northward displacements $(300 \mathrm{~km})$ were observed for the summer campaign due to stronger winds and along-shelf currents observed in this season.

\section{SUMMARY AND CONCLUSIONS}

This article describes the first long-term measurements of nearbottom currents and sea level off Ponta Negra Beach inner shelf, city of Natal, RN, Brazil. The mooring time series cover the spring, summer and fall seasons, with 96 days of observations. The data were combined with tide measurements from the Port of Natal and winds derived from the ERA-Interim reanalysis.

Sea level data from the Port of Natal and from the mooring point revealed that $98 \%$ of the spectral energy is concentrated in the semidiurnal band and about $1.02 \%$ in the diurnal band of the tides. The meteorological and low frequency bands only compose 

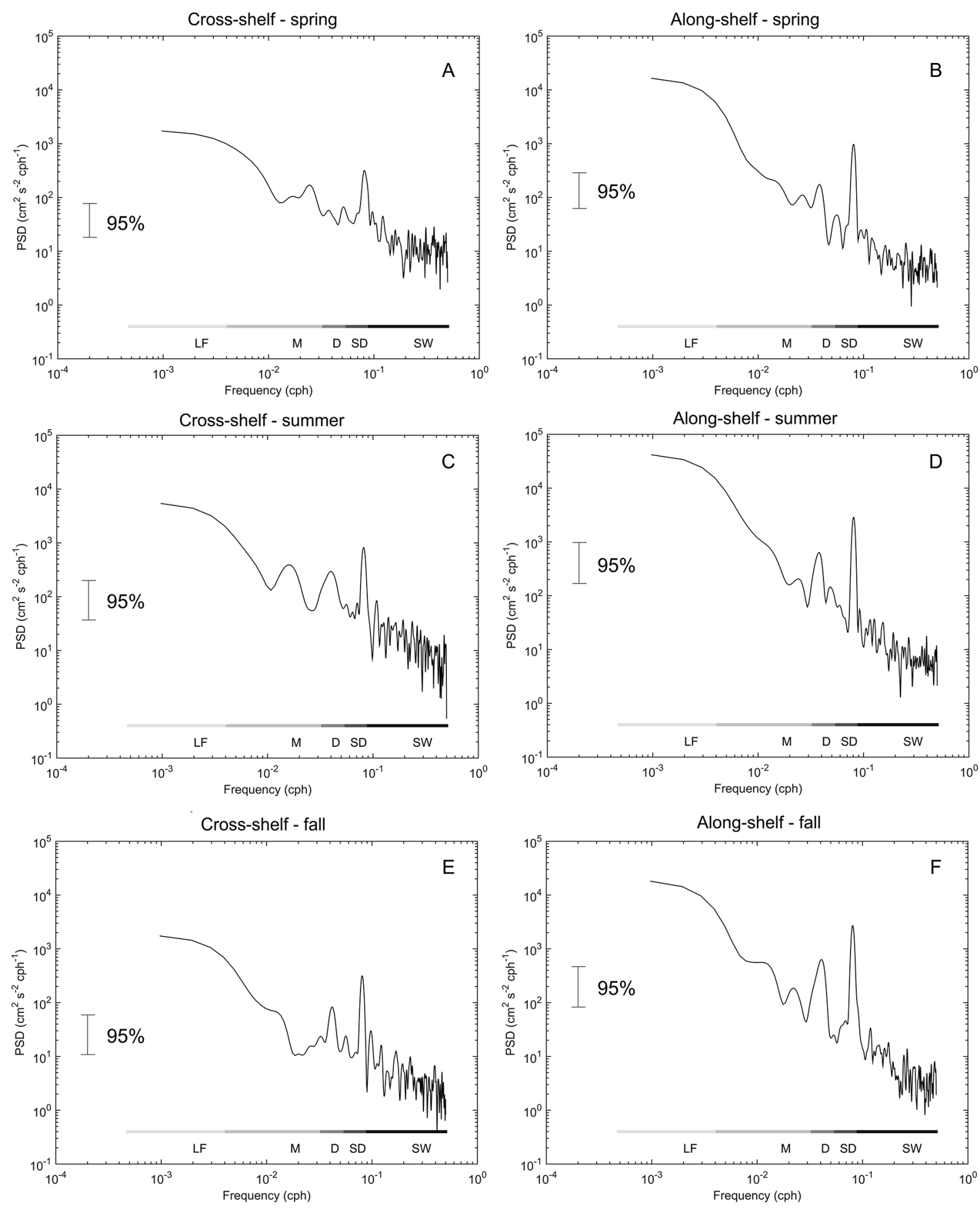

Figure 10 - Comparison between the cross-shelf $\left(U_{x}\right)$ and along-shelf $\left(V_{y}\right)$ velocity components during the spring, summer and fall campaigns. The letters LF, M, D, SD and SW refer, respectively, to the low frequency, meteorological, diurnal, semidiurnal and shallow water bands. PSD refers to power spectral density (cm² $\mathrm{s}^{-2}$ $\left.\mathrm{cph}^{-1}\right)$. 


\section{Progressive vector diagram}

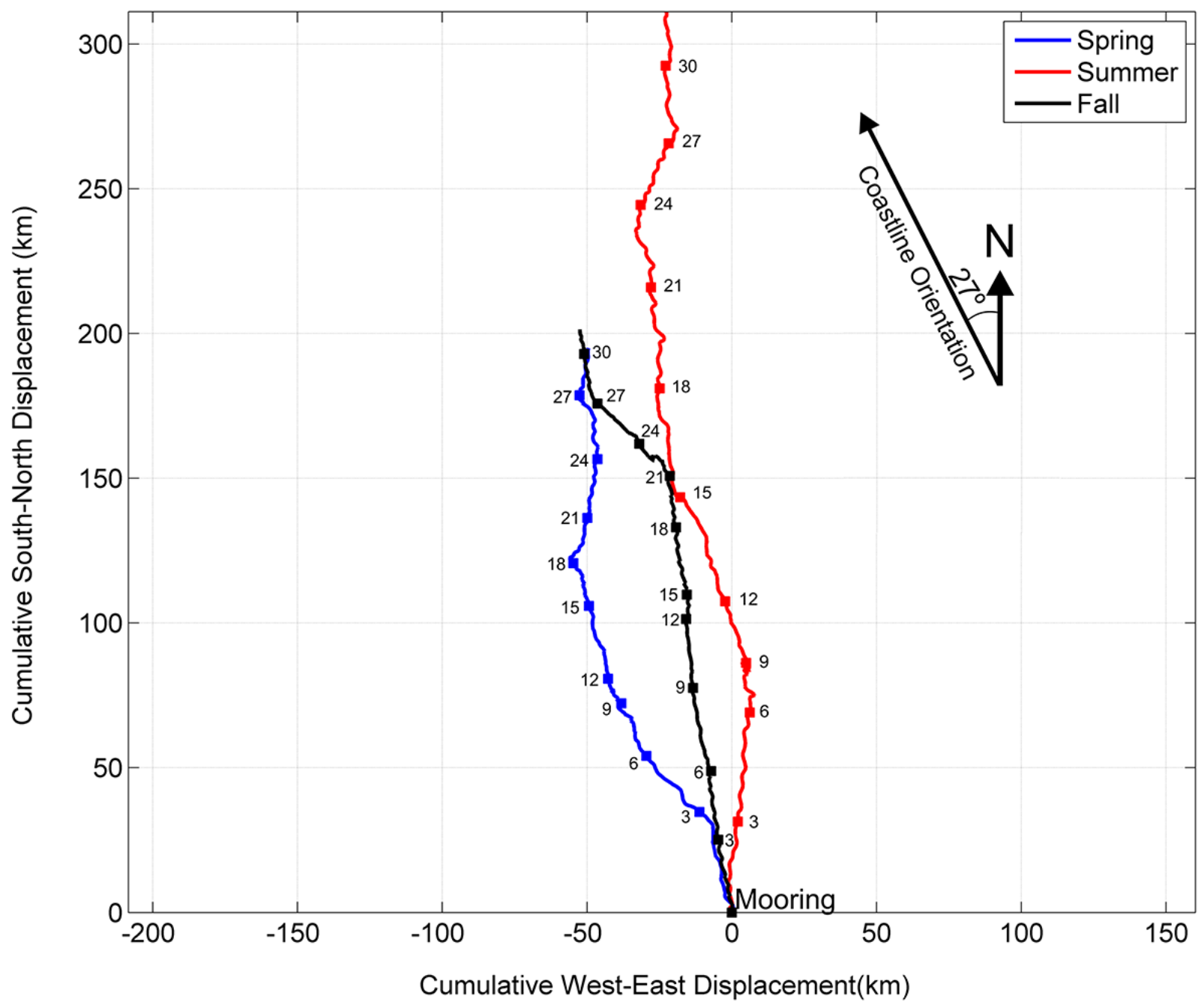

Figure 11 - Progressive vector diagram of near-bottom currents $(U, V)$ for the spring, summer and fall. Labels indicate time elapsed in days for each of these mooring campaigns.

about $0.76 \%$ of the sea level spectral energy, with more intense shallow water components for the estuary. Although having low amplitude, the subtidal signal of the sea level is strongly correlated with the along-shelf winds and currents.

Near-bottom currents over the inner continental shelf adjacent to Ponta Negra Beach are predominantly to the north. The greatest intensities were measured in the summer campaign, with median of $12.86 \mathrm{~cm} \mathrm{~s}^{-1}$, followed by fall with $8.02 \mathrm{~m} \mathrm{~s}^{-1}$ and spring with $9.31 \mathrm{~m} \mathrm{~s}^{-1}$. The spectral analysis indicated that the along-shelf component is more energetic over the low frequency and meteorological bands, which together account from $65 \%$ to $81 \%$ of the spectral energy. For the cross-shelf component, these bands account for 47 to $53 \%$. Shallow-water, semidiurnal and diurnal bands together account for 47 to $53 \%$ of cross-shelf component spectra, compared to 19 to $35 \%$ for the along-shelf component.

The combined analysis of correlations, with the partition of spectral energy and the progressive vector diagrams suggests that the residual along-shelf near-bottom flow is predominantly driven by winds. The mean circulation is predominantly to the north and parallel to the coastline. The data from the summer campaign estimate a displacement of $335 \mathrm{~km}$ to the north and $25 \mathrm{~km}$ to the west during 33 days. During the spring and fall, the residual displacement was approximately $200 \mathrm{~km}$ to the north and about $50 \mathrm{~km}$ to the west in approximately 30 days. 


\section{ACKNOWLEDGEMENTS}

The authors are thankful for technical support of Canindé and Júnior from UFRN during all field work and mooring operations. FR acknowledges CNPq and CAPES for his scholarships. FMP acknowledges CNPq grants (486381/2013-7, 406801/2013-4, 465672/2014-0, 311930/2016-6) for support. HV acknowledges the support of CNPq (311413/2016-1). This work was financed by the CNPq Universal Grant (486451/2012-7) and is a contribution to INCT AmbTropic (565054/2010-4, 8936/2011, 465634/2014-1 CNPq/FAPESB/CAPES).

\section{REFERENCES}

BARROS JD. 2013. Sazonalidade do vento na cidade de Natal/RN pela distribuição de Weibull. Sociedade e Território, Natal, 25(edição especial 2): 78-92.

BEARDSLEY RC, CANDELA J, LIMEBURNER R, GEYER RW, LENTZ SJ, CASTRO BM, CACCHIONE D \& CARNEIRO N. 1995. The M2 tide on the Amazon shelf. Journal of Geophysical Research, 15(100): 2283-2319.

CARRASCOZA LS. 2011. Hidrocarbonetos alifáticos em sedimentos de fundo do estuário do Rio Potengi, grande Natal (RN): Implicações ambientais. Master Dissertation, Programa de pós-graduação em Ciências e Engenharia do Petróleo, UFRN, RN, Brazil. 107 pp.

CASTRO BM \& MIRANDA LB. 1998. Physical oceanography of the western Atlantic continental shelf located between $4^{\circ} \mathrm{N}$ and $34^{\circ} \mathrm{S}$ costal segment (4'W). In: ROBINSON AR \& BRINK KH. The Sea. Oxford, John Wiley \& Sons. pp. 209-251.

CASTRO BM, DOTTORI M \& PEREIRA AF. 2013. Subinertial and tidal currents on the Abrolhos Bank shelf. Continental Shelf Research, 70: 3-12.

CAVALCANTI IFA, FERREIRA NJ, SILVA MGAJ \& DIAS MAFS. 2009. Tempo e clima no Brasil. São Paulo: Oficina de Textos, 463 pp.

COSTA RL \& MÖLLER 00. 2011. Estudo da estrutura e da variabilidade das correntes na área da plataforma interna ao largo de Rio Grande (RS, Brasil), no sudoeste do Atlântico Sul, durante a primavera-verão de 2006-2007. Revista da Gestão Costeira Integrada, 11(3): 273-281.

CSANADY GT. 1982. Circulation in the Coastal Ocean. D. Reidel Publishing Co., Dordrecht, Holland, $279 \mathrm{pp}$.

DEE DP et al. 2011. The ERA-Interim reanalysis: Configuration and performance of the data assimilation system. Quart. J.R. Meteorol. Soc., 137: 553-597.

DIAS FJS, CASTRO BM \& LACERDA LD. 2011. Circulação na plataforma continental ao largo do estuário do rio Jaguaribe (Ceará - nordeste - Brasil), durante a estação chuvosa de 2009. In: V Simpósio Brasileiro de Oceanografia-SBO, Brazil; Livro de Resumos.
EMERY WJ \& THOMSON RE. 2001. Data analysis methods in physical oceanography, Elsevier Science, Amsterdam, Holland. ISBN: $9780444507563,638 \mathrm{pp}$.

FRAZÃO EP. 2003. Caracterização hidrodinâmica e morfo-sedimentar do estuário Potengi e áreas adjacentes: Subsídios para controle e recuperação ambiental no caso de derrames de hidrocarboneto. Master Dissertation, Programa de Pós-graduação em Geodinâmica e Geofísica, UFRN, RN, Brazil. 195 pp.

GARVINE RW. 1999. Penetration of buoyant coastal discharge onto the continental shelf: a numerical model experiment. Journal of Physical Oceanography, 29: 1892-1909.

GARVINE RW. 2004. The vertical structure and subtidal dynamics of the inner shelf off New Jersey. J. Mar. Res., 62: 337-371.

GEYER RW \& KINEKE GC. 1995. Observations of currents and water properties in the Amazon frontal zone. Journal of Geophysical Research, 15(100): 2321-2353.

LARGE WG \& POND S. 1981. Open Ocean Momentum Flux Measurements in Moderate to Strong Winds. J. Phys. Oceanogr., 11: 324-336.

LENTZ SJ. 1994. Current dynamics over the Northern California innershelf. Journal of Physical Oceanography, 24(12): 2461-2478.

LENTZ SJ. 1995. The Amazon River Plume during AMMASSEDS: Subtidal current variability and the importance of wind forcing. Journal of Geophysical Research, 15(100): 2355-2375.

MELLOR GL. 1996. Introduction to Physical Oceanography. AIP Press, 1: 147-173.

MIRANDA LB, CASTRO BM \& KJERFVE B. 2002. Princípios de Oceanografia Física de Estuários, Edusp (Editora da Universidade de São Paulo), São Paulo, SP, Brazil, ISBN: 85-314-0675-7, 414 pp.

MIYAO SY \& HARARI J. 1989. Estudo preliminar da maré e das correntes de maré da região estuarina de Cananéia $\left(25^{\circ} 5-48^{\circ} \mathrm{W}\right)$. Boletim do Instituto Oceanográfico, São Paulo, 37(2): 107-123.

NEIVA EJF. 1975. An investigation of wave-type disturbances over the Tropical South-Atlantic. M.Sc. Thesis. Naval Post Graduate School, Monterey, California, USA, 58 pp.

OLIVEIRA RRC \& SILVA AG. 2013. Análise da tendência do regime de chuva nas cidades de Mossoró-RN e Natal-RN de 1986 até 2007. IX CONGIC - Congresso de Iniciação Científica da Universidade Federal do Rio Grande do Norte, Brazil, p. 869-878.

PALOWICZ R, BEARDSLEY B \& LENTZ S. 2002. Classical tidal harmonic analysis including error estimates in MATLAB using T_TIDE. Computers \& Geosciences, 28(8): 929-937.

PEREIRA TRB. 2013. Aplicação da batimetria multifeixe para análise da morfologia do fundo marinho adjacente à Ponta Negra Beach - RN. UFRN, Brazil, Undergraduate Final Project, Geophysics, 42 pp. 
PIMENTA FM, MELO FILHO E, FRANCO D \& ZAVIALOV P. 2004. Assessment of Santa Catarina Shelf Currents through the Analysis of Indirect Measurements. Journal of Coastal Research, (SI 39): 651-655 (Itajaí-SC).

PIMENTA FM, GARVINE R \& MÜNCHOW A. 2008. Observations of coastal upwelling off Uruguay downshelf of the Plata estuary, South America. Journal of Marine Research, 66: 835-872.

PIMENTA FM, KIRWAN AD \& HUQ P. 2011. On the Transport of Buoyant Coastal Plumes. Journal of Physical Oceanography, 41: 620 640.

PINGREE RD \& GRIFFTHS DK. 1979. Sand transport paths around the British Isles resulting from M2 and M4 tidal interactions. J. Mar. Biol. Ass. U.K., 59: 497-513.

PUGH DT. 2004. Changing sea levels. Effects of weather tides and climate. Cambridge University Press, 280 pp.

SCHOTT FA, DENGLER M, ZANTOPP R, STRAMMA L, FISCHER J \& BRANDT P. 2005. The shallow and deep western boundary circulation of the South Atlantic at $5^{\circ}-11^{\circ} \mathrm{S}$. J. Phys. Oceanogr., 35: 2031-2053.

SILVA AR, PIMENTA FM, ASSIREU AT \& SPYRIDES MHC. 2016. Complementarity of Brazil's hydro and offshore wind power. Renewable and Sustainable Energy Reviews, 56: 413-427.

SILVEIRA ICA, SCHMIDT ACK, CAMPOS EJD, GODOI SS \& IKEDA Y. 2000. A Corrente do Brasil ao largo da Costa Leste Brasileira. Rev. Bras. Oceanogr., 48(2): 171-183.

Recebido em 21 abril, 2017 / Aceito em 4 outubro, 2017

Received on April 21, 2017 / Accepted on October 4, 2017
TEIXEIRA RSB. 2008. 0 fenômeno da brisa e sua relação com a chuva sobre Fortaleza-CE. Revista Brasileira de Meteorologia, 23(3): 282-291.

TEIXEIRA CEP, LESSA GC, CIRANO M \& LENTINI CAD. 2013. The inner shelf circulation on the Abrolhos Bank, $18^{\circ} \mathrm{S}$, Brazil. Continental Shelf Research, 70: 13-26.

VITAL H. 2006. Rio Grande do Norte. In: MUEHE D (Org.). Erosão e progradação do litoral brasileiro. Brasília, Brazil: MMA. p. 155-171.

VITAL H. 2014. The north and northeast Brazilian tropical shelves Geological Society, London, Memoirs, 41: 35-46.

VITAL H, TABOSA F, FRAZÂO EP, SANTOS CLA \& PLACIDO JS 2010. Characterization of the Brazilian continental shelf adjacent to Rio Grande do Norte State, NE Brazil. Brazilian Journal of Oceanography, 58(Special Issue 1): 43-54.

WELCH P. 1967. The use of fast Fourier transform for the estimation of power spectral: a method based on time averaging over short, modified periodograms. Audio and Electroacoustics, IEEE Transactions (ISSN: 0018-9278).

WRIGHT LD. 1995. Morphodynamics of inner continental shelves, Boca Raton, FL: CRC Press, $241 \mathrm{pp}$

ZAVIALOV P, MÖLLER Jr. 0 \& CAMPOS E. 2002. First Direct measurements of currents on the continental shelf of Southern Brazil. Continental Shelf Research, 22: 1975-1986. 